\title{
'ONE OF THESE DAYS I'M GONNA PAY IT BACK': DEBT COLLECTION PRACTICES IN NEW ZEALAND - WHAT NEW RESEARCH HAS REVEALED
}

\author{
Victoria Stace, ${ }^{*}$ Maisy Bentley, ${ }^{* *}$ Hanna Malloch ${ }^{* * *}$
}

Recent research conducted by Victoria University of Wellington provides evidence of debt collection practices in New Zealand. This article discusses the findings of the research and makes recommendations to assist in addressing issues around harassment, use of attachment orders and accumulation of interest on old debts.

\section{INTRODUCTION}

Most people would agree that if you borrow money, you should pay it back. Or if you are provided with a service, such as power or phone, you should pay for it. But what happens if your circumstances change so that you find yourself unable to pay that bill or that lender? People find themselves unable to pay back their debts for many reasons. What can then happen is that the lender or service provider, after making several demands for payment, might give the debt to a debt collection agent. Alternatively, or after collection attempts by an agent have failed, they might sell the debt to a debt purchaser, who then seeks to recover it from the debtor. Both a debt collection agent and debt purchaser are included in the term 'debt collector' in this article.

While a debt collector is not expected to proceed "as if at a prayer meeting", ${ }^{1}$ most people would also agree that the collection process should be done with compassion and an acknowledgement of what is realistically possible for the debtor. Does the law have a role to play in ensuring that this

$\dagger \quad$ Elvis Costello "Pay it back" (from the album "My Aim is True" released 22 July 1977).

* Senior Lecturer, Victoria University of Wellington.

** Research assistant and Law Student, Victoria University of Wellington.

*** Research assistant and Law Student, Victoria University of Wellington.

1 Australian Securities and Investments Commission v Accounts Control Management Services Pty Ltd [2012] FCA 1164 at [14] Per Perram J. 
standard is adhered to? There is currently little in the way of targeted regulation around the conduct of debt collectors, under New Zealand law.

The Ministry of Business, Innovation and Employment (MBIE) recently conducted a review of consumer credit regulation in New Zealand. The official papers and submissions generated by that review revealed that there are issues with the way debt collection has been conducted by some debt collectors. The only reform that came out of that review was an amendment to the Credit Contracts and Consumer Finance Act 2003 (CCCFA), which is expected to come into effect late in 2021. The amendment will require certain disclosures at the start of the debt collection process, if the debt was created by a consumer credit contract.

This article draws on recent research that has been done by Victoria University of Wellington (in association with $\mathrm{FinCap}^{2}$ ) that has obtained data on the types of practices that have been employed by debt collectors in New Zealand. A full report of the research is available from the FinCap website. ${ }^{3}$ That research focused on three key aspects of debt collection: conduct of debt collectors towards debtors; the addition of fees and interest to the debt; and the use of attachment orders. The research does not provide quantitative data on the number of consumers pursued by debt collectors or the size of the debt collection market, which were matters identified by MBIE as lacking in data. ${ }^{4}$ But it does provide data on the experiences of debtors. This article summarises the findings of the research and includes comments on each of those areas. It also makes a series of recommendations.

Two debt collection practices that were revealed by the research would appear to be particularly egregious. These are:

(1) Sending an intimidating-looking person, or a collector dressed in police or army clothing, to the debtor's house to collect a debt; and

(2) allowing a debt to lie dormant for a period of years while continuing to add interest, then getting a default judgment against the debtor followed by an attachment order against the debtor's income (which in many cases is a Work and Income benefit). This means that the debtor ends up paying off a significantly larger debt often over a very long period, via automatic deductions from their benefit or wages.

2 FinCap, formerly the National Building Financial Capability Charitable Trust, is a non-government organisation that acts as the umbrella organization for the approximately 200 free financial mentoring services around New Zealand. See <www.fincap.org.nz>.

3 Victoria Stace and Liz Gordon Debt Collection in Aotearoa from the perspective of financial mentors (Fincap, September 2021) <www.fincap.org.nz>.

4 Ministry of Business, Innovation and Employment Impact Statement: CCCFA Amendments (24 September 2018) at 52-53. 
These practices, and others that were revealed by the research, indicate there is an urgent need for an MBIE review of debt collection practices with a view to possible regulation of debt collection activity.

This article makes the following recommendations which highlight aspects in which changes could be made to address certain types of harm arising from current practices, in particular, affecting vulnerable consumers.

(1) The Fair Trading Act 1986 (FTA) prohibition on harassment and coercion in s 23 should be amended to bring it into line with the wording in the Australian Consumer Law, and breach of s 23 made an offence.

(2) The Commerce Commission should then develop detailed guidelines setting out the regulator's views on what constitutes harassment under s 23 of the FTA, using the Australian Debt Collection Guidelines as a model. ${ }^{5}$

(3) Those guidelines should include that allowing a debt to lie dormant, while continuing to accrue interest for a period after the debt collection process has started (which could be either by the referral of the debt to a debt collection agent or by sale of the debt), then seeking a default judgment is likely to be considered oppressive conduct under the CCCFA. The period could be set after consultation with stakeholders. The courts have suggested that legal proceedings culminating in a default judgment should be taken within 12 months after default by the debtor. ${ }^{6}$

(4) The guidelines could also set out the regulator's approach to assessment of reasonableness of fees as a way of setting industry standards.

(5) Thought should be given to the possibility of amending the CCCFA to provide a prohibition on charging interest (or default interest) in relation to a consumer credit contract once the debt collection process has started.

(6) The initial disclosure rules under the CCCFA should require more detailed disclosure of the fees and charges that might become payable in the event that the debtor defaults and a debt collection procedure is commenced.

(7) A review of the use of attachment orders by creditors (including debt purchasers) should be undertaken with a view to considering whether the District Court Act 2016 should be amended to protect 100 per cent of income from Work and Income (in other words, a benefit), and possibly an equivalent threshold for wages, from the attachment order process. At the least, the Court should be required to view more detailed information on the debtor's financial situation before it makes an attachment order where the debtor is a beneficiary.

5 Australian Competition and Consumer Commission (ACCC) and Australian Securities and Investments Commission (ASIC) Debt Collection Guideline: for collectors and creditors (April 2021).

6 See Aotea Finance (West Auckland) Ltd v Hiku [2015] NZDC 22553 [Aotea Finance] at [12]. 


\section{BACKGROUND}

Evidence gained in the course of a recent review of consumer credit regulation by MBIE, which focused primarily on the high-cost lending industry, suggested that there have been problems around debt collection. In 2017 and 2018, MBIE spoke to various interested parties, including consumer advocates, lenders, the Commerce Commission and industry bodies. The evidence gained from that consultation was collated in a discussion paper released by MBIE in June 2018 (the June 2018 Discussion Paper). ${ }^{7}$ That paper stated that complaints to the Commerce Commission about debt collection have been steadily rising. ${ }^{8}$ The Additional Information Document, which was released by MBIE at the same time as the June 2018 Discussion Paper, reported that: ${ }^{9}$

It is likely that debt collection issues are under-reported. We have heard that consumers are reluctant to complain about debt collector behaviour or irresponsible lending for a range of reasons, including shame, fear, or a lack of knowledge of rights and processes surrounding complaints.

The 2018 Discussion Paper recorded that problems were occurring in these areas in particular: ${ }^{10}$ false or misleading claims being made by debt collectors; debt collectors requiring debtors to comply with unaffordable repayment schedules; excessively large fees being charged for debt collection (which were being passed on to the debtor); and harassment of debtors, including frequent phone calls and some aggressive or coercive behaviour.

Submissions made to the June 2018 Discussion Paper over the subsequent consultation period (June to August 2018) provided additional evidence of problems with debt collection. Submissions to the June 2018 Discussion Paper came from lenders, the regulator, debt collectors, financial mentoring services and others. Almost every submission commented on problems concerning debt collection.

A key theme that emerged from those submissions was that many consumers, as debtors, have experienced conduct from debt collectors that might amount to harassment or coercion. ${ }^{11}$ One dispute

7 Ministry of Business, Innovation and Employment Discussion Paper: Review of Consumer Credit Regulation (June 2018).

8 At 35. In 2017-2018, the Commerce Commission received 125 complaints about debt collection, 84 complaints about responsible lending, 65 complaints in relation to disclosure practices and 54 complaints about fees. Commerce Commission Consumer Issues 2017/18 (27 November 2018) at 3.

9 Ministry of Business, Innovation and Employment Review of consumer credit regulation: Additional information to support the discussion paper (June 2018) at 22 and 23.

10 Ministry of Business, Innovation and Employment, above n 7, at 35-36.

11 See submissions of Christians Against Poverty, Christian Budgeting, Family Finances Services, FinCap and Waahi Whaanui Trust to the June 2018 Discussion Paper (above n 7). Other issues that emerged from the submissions included debt collectors being intimidating, ignoring do not knock signs, "bombing" debtors with text messages, dressing like policemen, using gang members to collect debt, making multiple phone calls (up to 33 calls in one day), and threatening to remove household goods or contact the debtor's employer. 
resolution scheme reported that consumers commonly allege that poor debt collection practices have occurred, including excessive phone calls and threatening behaviour. ${ }^{12}$ Even lenders stated that debt collectors can be aggressive and behave both irresponsibly and illegally. ${ }^{13}$

The only reform targeted at debt collection practices that was recommended by MBIE was to increase the disclosure requirements at the beginning of the debt collection process. The September 2018 Regulatory Impact Statement that preceded the Credit Contracts Legislation Amendment Bill stated that this reform was recommended because: ${ }^{14}$

[Prescribed disclosure] has significant benefits, especially around improved transparency and enhanced self-enforcement opportunities. Accurate information would benefit debtors, who could more readily understand the debt, work with debt collectors to establish a repayment plan, and challenge the debt if necessary. It would also benefit debt collectors, who could resolve the debt more readily if all parties understood key facts of the loan.

This amendment has been enacted in the Credit Contracts Legislation Amendment Act 2019 and is expected to come into effect in late 2021. The new provision will require all debt collectors (agents and debt purchasers), when collecting in relation to a consumer credit debt, to disclose certain information at the start of the debt collection process. The disclosure obligation will arise if the debtor is a natural person, the debt arises from a credit contract, the credit was to be used for personal, domestic or household purposes and the debt collection is carried out in the course of a business. ${ }^{15}$ If the debt is collected by an agent on behalf of the creditor, the obligation to disclose will fall on the debt collector. ${ }^{16}$

Notwithstanding that there appeared to be a range of problems with the debt collection process, no other reforms were supported by MBIE. This may have been in part due to the fact that debt collection issues extend beyond consumer credit contracts and that the review was only of consumer credit regulation. Service providers, such as phone and power companies, engage collection agencies

12 See submission of Insurance and Financial Services Ombudsman to the June 2018 Discussion Paper, above n 7.

13 See submissions of DCO Finance, Rapid Loans and the Financial Services Federation to the June 2018 Discussion Paper, above $n 7$.

14 See Ministry of Business, Innovation and Employment, above n 4, at 56.

15 Credit Contracts Legislation Amendment Act 2019, s 51. This amendment act inserts s 132A into the Credit Contracts and Consumer Finance Act 2003 which was expected to come into force from 1 October 2021 (commencement has been impacted by Covid and has been delayed to December 2021).

16 "Debt collector" in respect of a contract, means a creditor or any other person engaging in debt collection in respect of the contract. See s $132 \mathrm{~A}(4)$. 
to collect debt and/or sell debt to debt purchasers. MBIE's response would also appear to have been in part due to the lack of data on the nature and extent of the issues. ${ }^{17}$

\section{THE 2021 VICTORIA UNIVERSITY RESEARCH ON DEBT COLLECTION PRACTICES (2021 RESEARCH)}

Aside from the evidence gathered by MBIE in the course of the consumer credit review, there has been little evidence gathered on the types of debt collection practices in use in New Zealand. In 2021, researchers at Victoria University of Wellington, in association with FinCap, set out to gather evidence by talking to financial mentors around New Zealand. Many of these mentors see clients who are dealing with unmanageable debt on a daily basis. Many clients seen by these mentors are vulnerable consumers as they are on a low income or on a benefit, lack good English skills, have mental health issues, or are solo parents or (often) are affected by a combination of those factors. ${ }^{18}$

Early in 2021, an invitation was extended to every free financial mentoring service in New Zealand and other organisations that provide financial mentoring services to participate in the research. Every service that responded was then given the opportunity to have one or more of its mentors interviewed by a researcher or to respond to the research questions in writing. The questions targeted three aspects of debt collection activity: harassment of debtors; adding fees and interest to the amount of the debt; and use of attachment orders. ${ }^{19}$

Key findings of the 2021 Research are set out in the following paragraphs.

Many mentors reported that their clients have experienced harassment by debt collectors. The most common type of harassing conduct was frequent phone calls and texts. There were also reports of threatening conduct, for example, the debt collector sending an intimidating-looking person around to the debtor's house.

The addition of debt collection fees to the debt (thereby increasing the amount of debt the debtor had to pay) was common. It was also common for debtors to have little understanding of how these fees and charges might be added to the debt. Sometimes interest continued to be added to the debt

17 MBIE indicated that it was operating under constraints, for example, it had received conflicting evidence on whether the problems are being caused by a small number of non-compliant debt collectors or whether the poor conduct was more widespread. MBIE noted that there is very little quantitative information on the extent of problems. See Ministry of Business, Innovation and Employment, above n 4, at 52-53.

18 Research undertaken for the Australian Competition and Consumer Commission (ACCC) in 2015 into the Australian debt collection industry (2015 Industry Research) found, as one of its key findings, that non-compliant debt collection practices result in significant detriment to vulnerable and disadvantaged consumers. See ACCC Research into the Australian Debt Collection Industry (2015).

19 See the full report: Stace, above n 3. 
after it had gone to a debt collector and on occasion, the debt purchaser continued to add interest to the purchased debt for several years before taking steps to collect the debt.

The use of court-ordered attachment orders to wages and benefits was common. The standard amount of an attachment order to a benefit appeared to be $\$ 30$ per week. Debtors were generally unaware of their rights at the time the attachment order was made (for example, to oppose the order or the amount sought to be deducted) or to apply to the court to have it altered. In the case of some debtors, in particular beneficiaries, the deduction from their income to pay the judgment creditor (who would often be the person who had purchased the debt) meant there was not enough left to buy food or other essentials.

\section{A Conduct of Debt Collectors towards Debtors}

\section{The data}

Many mentors stated that their clients had experienced conduct that might be considered to amount to harassment. A common form of harassment was persistent phone calls and emails. Sometimes there would be calls made to the debtor's workplace. Below are some representative quotes from the data: ${ }^{20}$

They contact [the debtors] multiple times throughout the day or throughout the week. One of my clients, just in the last couple of weeks, said he was contacted at 9 o'clock at night by a debt collector.

They ring the workplace. That was even after I had contacted the debt collector and they had on file that they were not to do that because this person had mental health issues as well. When they called the office the boss then called him in and wanted to know what was going on.

A client that was rung at their work about their debt by a debt collection company [was] very humiliated by this especially as they were a carer at a rest home and it wasn't in a lunch break. Somehow, they had found out who she was working for as the call came through the receptionist.

Repeated calls at work, where you are going either to a personal phone number, or actually in this case, actually through the main work number. And in that, threatening to attend the workplace and have those conversations about debt collection in the workplace, in front of colleagues and bosses etc.

The other day, they called me, they texted me, then they emailed me. I was busy with a client so couldn't work with them, so then they rang the office and asked for the manager. It can be like 5 times, just one after the other.

20 Transcripts of the interviews may be made available on request, subject to participant consent. Requests can be made to: Victoria.Stace@vuw.ac.nz. 
Some mentors reported incidents of bullying or threatening conduct:

They were rude, dismissive and I believe quite threatening in the fact that they kept telling her if you don't sort it out by the next 48 hours then this is going to happen and if you don't sort it out then this is going to happen. All the while she's confused, rightly, because to her knowledge she doesn't have debt.

Somebody had sent a fraud investigator to their house. That happens a lot with those buying debt, because the client is saying 'I've got no money'. It's fear tactics, somebody like that rocks up to your house you're going to say, 'yes give me the piece of paper'.

Debt collector lying to the debtor e.g., saying if a certain amount is not paid by a certain time then debt collector will repossess goods when they have no legal basis to do so.

The types of harassment that I have seen are the debt collector threatening to tell the client's family or friends about the debt and threatening to try and collect the debt from that other person.

I have had a client who is a church leader or elder be threatened with exposure if he did not make required payments to a creditor. The person who did this works for a high-cost lender they told my client that they would tell the people at his church that he was not paying his debt.

Several mentors reported that debt collectors had sent an intimidating person to the house of the debtor:

The [debt collection] company door knocks to all their debtors and this guy is absolutely huge, he's built like a brick shit house, he's wearing stab proof vest and he's got a camera. And it's the intimidation. If someone opens the door and sees him there, they're going to say, 'oh yeah I can pay you $\$ 50$ a week'. So, my argument is if he's got a stab proof vest and a camera why does he need to be 7-foot-wide and half that sideways.

When there is a home visit there can often be intimidation behaviour. That intimidation behaviour can often just be a big burly Pacifica guy just turning up or somebody with see-able patch markings. There is one debt collection agency out there, I can't remember which one it is, and they often turn up in full gear as if they're like police. They have vest and walkie talkies and the full gear.

You also come across things like where some of these debt collection agents employed by the agencies look like police. They're in dark uniforms and one company even had police type vest on like the police wear and this puts the fear of the lord into them when they turn up at their home and all the neighbours are looking and all that carry on. And that's all a part of the tactics of trying to get them to fork out.

Especially one of the collection agencies, they dress up in army clothes and go to people's house, knocking on the client's door. Like, one of the clients down in [name of place], this guy came to the door and was dressed in army ... really demanding, like, 'you need to pay this money, otherwise ...' and they keep going to the client's house until they sort something out. 
One mentor reported an example of deceptive conduct in an attempt to get a phone number:

It's the blank pages that the clients get in the post saying please call this number regarding a confidential matter and quote this reference number. So, there's no letterhead or indication of what it is, it doesn't look legal anymore because it's now illegal to do that but it looks so official that a lot of clients call and all of a sudden the debt collector has their phone number and the harassment starts.

\section{Comment on conduct of debt collectors towards debtors}

While there is no law in New Zealand that is targeted at conduct by debt collectors, the following Acts can be relevant.

Under the FTA, s 23 prohibits using physical force, harassment or coercion in connection with the payment for goods or services, which is enforceable against debt collectors who act as agents and debt collectors who purchase debt. Breach of s 23 is not a criminal offence. If the court finds that a person has suffered loss or damage by reason of the conduct, it can make a variety of orders, most relevantly, compensation for the loss or damage. ${ }^{21}$

The FTA is enforced by the Commerce Commission. The Commerce Commission has issued a guidance note entitled "Guidance for debt collectors" which explains that it is unlawful to harass or coerce someone into repaying debt and gives one example (from the Australian case of ACCC $v$ Accounts Control Management Services Pty Ltd ${ }^{22}$ ) of what might be harassment or coercion. ${ }^{23}$ The guidance note is in very general terms and does not address specific issues such as what time of day it is appropriate to contact a debtor or how often.

There is no definition of what constitutes harassment or coercion for the purposes of this Act. ${ }^{24}$ There has been some regulatory action enforcing the prohibition in the FTA on harassment in the context of debt collection. ${ }^{25}$

21 Fair Trading Act 1986 [FTA], s 43.

22 Australian Competition and Consumer Commission v Accounts Control Management Services Pty Ltd [2018] FCA 1115.

23 See Commerce Commission Guidance for Debt Collectors (June 2019).

24 There is a limited amount of New Zealand case law interpreting s 23. See Victoria Stace "Debt Collection in New Zealand: Enlivening the Prohibition against Harassment and Coercion in s 23 of the Fair Trading Act 1986" (2020) 26 NZBLQ 3 at 16-17.

25 The only enforcement action by the Commerce Commission that relates directly to the prohibition on harassment or coercion appears to be a warning issued to Twenty Five Station Ltd and its director in relation to conduct that the Commission considered might have amounted to harassment or coercion. In the Commission's view, Mr Campbell and Twenty Five Station Ltd (which traded as Law Debt Collection) engaged in conduct with one person that was also likely to amount to harassment and/or coercion because of the volume, tone and content of the correspondence. See Commerce Commission "Debt collector warned for 
The Fair Trading Amendment Bill, given Royal Assent on 16 August 2021, introduces a prohibition on unconscionable conduct in trade, which will be enforceable against both debt collection agents and debt purchasers (this prohibition will come into effect in August 2022). A breach will give rise to an offence or civil proceedings. It is possible that some of the types of conduct mentioned above could be found to amount to unconscionable conduct. The threshold for unconscionable conduct, based on Australian law, is high. ${ }^{26}$ In summary, what must be shown is that the conduct in question was more than simply unfair-it must be against conscience as judged against the norms of society. ${ }^{27}$ Australian courts have found transactions to be unconscionable where deliberate, involve serious misconduct or where evidently unfair and unreasonable conduct is involved. Unconscionable conduct is generally considered to be a higher standard than oppressive conduct, at least under the equitable doctrine of unconscionability (which the Australian courts look to when applying the statutory prohibition). ${ }^{28}$

A person who has been harassed can take action against the person who did the harassing under the Harassment Act 1997. An application to the District Court under this Act can result in a restraining order against the harasser. Criminal prosecution for harassment is also possible. 'Harassment' is defined for the purposes of this Act as engaging in a pattern of behaviour that is directed against that other person, being a pattern of behaviour that includes doing any 'specified act' to the other person on at least two separate occasions within a period of 12 months. Specified acts include a wide range of behaviour, such as stalking, abusive phone calls and threatening letters. This Act is aimed at protection of victims of harassment, in particular, in a family context where the victim fears for their safety. The Harassment Act has not generated any case law showing its use in the context of debt collection.

All debt collectors (agents and purchasers) are subject to the privacy principles under the Privacy Act 2020. The principles impose, for example, limits on disclosing personal information about a

likely harassment, coercion, misleading claims" (13 December 2019) Commerce Commission New Zealand <www.comcom.govt.nz>.

26 After considering the options put forward by MBIE to address unfair conduct in business, the Government opted for a prohibition on unconscionable conduct, for the apparent reason that "this will support alignment with Australia and allow New Zealand to draw on Australian case law." See Ministry of Business, Innovation and Employment Impact statement: Protecting business and consumers from unfair commercial practices $(20$ June 2019) at 2.

27 Australian Competition and Consumer Commission v Lux Distributors Pty Ltd [2013] FCAFC 90 at [41].

28 Bartle v GE Custodians Ltd [2010] NZCA 174 at [177]-[178]; and J Paterson "Unconscionable bargains in equity and under statute" (2015) 9 J Eq 188. 
debtor's affairs to third parties. There has been some regulatory action against debt collectors to enforce privacy laws. ${ }^{29}$

Harassment of debtors by debt collectors has also been an issue in Australia. Australia has taken a regulatory step that has succeeded in raising the standards of debt collection conduct across the industry. The Australian Competition and Consumer Commission (ACCC) and the Australian Securities and Investments Commission (ASIC) have introduced a set of comprehensive guidelines setting out their view on what is and is not acceptable behaviour for debt collectors. ${ }^{30}$ The Australian Guidelines relate to two pieces of legislation, the Australian Consumer Law (ACL) and the Australian Securities and Investments Commission Act (ASIC Act). The ACL is broadly comparable to New Zealand's FTA. It provides a framework of protection for consumer transactions within Australia. In particular, it contains prohibitions on misleading conduct in trade, on certain types of misrepresentations and on harassment and coercion. The other relevant piece of legislation in Australia is the ASIC Act. ASIC is responsible for dealing with misconduct associated with collection of debts that arise from financial services. There is no provision in the New Zealand Financial Markets Conduct Act 2013 that addresses harassment or coercion. However, this type of conduct in the context of financial services could be addressed by the Commerce Commission using its power in $\mathrm{s} 23$ of the FTA.

The Australian Guidelines set out the regulators' view, expressed as "practical guidance", ${ }^{31}$ on what is and is not acceptable conduct by debt collectors (agents and purchasers) in relation to all types of consumer debt. They provide guidance on how Australian laws apply to all debt collectors. The term 'debt collector' includes a debt collection agency, a debt purchaser and an in-house debt collection division of a business. The Australian Guidelines also provide guidance to the person that was originally owed the debt, who will remain responsible for the conduct of the agent, if they use a debt collection agent to collect the debt. Where debt is sold, the original owner of the debt remains responsible for misconduct that occurred before the debt was sold. The Australian Guidelines are also

29 In 2016, the Privacy Commissioner investigated and reported on a breach of principle 8 of the information privacy principles by a debt collection agency, Law Debt. The facts involved a disputed debt with a childcare centre. When contacted by Law Debt, the complainant informed Law Debt that the debt was disputed. Law Debt nonetheless continued to pursue him and eventually referred the debt to a credit reporting agency. The Privacy Commissioner found that Law Debt had breached principle 8 of s 6 of the Privacy Act 1993 because Law Debt did not take reasonable steps to check that the information regarding the debt was accurate, up to date, and not misleading before using it. See Privacy Commission "Case note 279069 [2016] NZ PrivCmr 12: Debt collector Law Debt fails to check accuracy of information before use" (5 December 2016) Office of the Privacy Commissioner <www.privacy.org.nz>.

30 ACCC and ASIC, above $\mathrm{n} 5$.

31 At 2 . 
intended to provide a reference point for financial counsellors when negotiating with debt collectors (and the debt owner) about the debt and/or debt collection practices. ${ }^{32}$

The Guidelines set out what is and is not acceptable conduct in relation to contacting debtors. They set out, for example, how debtors may be contacted, reasonable times to make contact and frequency of contact and rules around visits to the home and workplace. In 2015, the ACCC commissioned research into the scale, scope and structure of the debt collection industry. The resulting report (2015 Industry Research) noted that the Australian Guidelines have resulted in improved behaviour within the debt collection industry and represent best practice. ${ }^{33}$ They were described as a "highly successful regulator initiative". ${ }^{34}$

The Australian Guidelines were referred to by many submitters to the June 2018 Discussion Paper. Many lenders and debt collectors suggested that New Zealand should adopt guidelines that mirrored the Australian Guidelines. ${ }^{35}$

The key legislative provisions that underpin the Australian Guidelines, as they relate to conduct of debt collectors towards debtors, are in most respects very similar to the comparable New Zealand provisions. However, there is a significant difference in relation to the prohibition on harassment and coercion.

The Australian prohibition is against "undue harassment and coercion" and breach leads to an offence (and payment of a fine) or payment of a pecuniary penalty. The corresponding New Zealand prohibition is against "harassment and coercion" and leads only to civil proceedings (including an injunction or an award of compensation for loss or damage). ${ }^{36}$ The FTA does not provide for pecuniary penalties but breach of some provisions (not including s 23) is an offence.

Neither of the terms "harassment" or "coercion" are defined in the FTA. The Commission has not taken any action under s 23 that has generated case law that assists in clarifying the meaning of the words "harassment" or "coercion". There have been some cases taken between private parties that

32 At 1 .

33 ACCC, above n 18 , at 6.

34 At 44.

35 See ANZ "Submission on the discussion paper, review of consumer credit regulation" at 11; Baycorp "Submission on discussion document: Consumer Credit Regulation Review" at 2 and 4-5; Credit Recoveries Ltd "Submission in Response to Discussion Paper - review of Consumer Credit Regulation" at 2; Financial Services Federation "Submission on Discussion Paper: Review of Consumer Credit Regulation June 2018" at 22-23; Illion "Submission on discussion document: Consumer Credit Regulation Review" at 5; Rapid Loans NZ Ltd "Submission on discussion document: Consumer Credit Regulation Review" at 22; and Sunshine Loan Centres Pty Ltd "Submission on discussion document: Consumer Credit regulation Review" at 17. Sunshine Loan Centres Pty Ltd is an Australian lender considering setting up business in New Zealand.

36 Fair Trading Act, ss 41 and 43. 
have focused on the meaning of those words and there is also Australian case law that has assisted in clarifying the meaning of "undue harassment and coercion". 37

It has been previously argued that while the adoption of guidelines by the New Zealand regulator that are modelled on the Australian Guidelines (referred to in this article as NZ Debt Collection Guidelines) makes a lot of sense - to clarify the standard of conduct expected of debt collectors in New Zealand - the fact that the FTA provision is worded differently from the equivalent provision in the ACL is problematic. ${ }^{38}$ Australian case law makes it clear that "harassment" is different from "undue harassment". In addition, breach of the New Zealand prohibition leads only to a limited range of civil proceedings. Guidelines in New Zealand based on the current law in the FTA would have to reflect the lower threshold of "harassment" in the s 23 prohibition and, therefore, would likely set out a different set of expectations for debt collectors in New Zealand by contrast to those operating in Australia. There would be benefits in aligning the prohibition in s 23 with the corresponding prohibition in the ACL, as this would allow harmonisation not only of the law (particularly relevant as some debt collectors operate in both jurisdictions), but also the regulatory response. Introduction of a higher threshold would also justify increasing the sanction by making it an offence to breach s 23 , in addition to allowing civil remedies. Making breach of s 23 an offence would also assist the Commission with enforcement as there would not be a need to prove that a person has suffered loss or damage from the breach.

Thought could be given to the possibility of requiring debt collection agents to be licensed if after the introduction of NZ Debt Collection Guidelines, there was no significant improvement in conduct towards debtors. In 2015, the law around repossession agents was amended to require repossession agents to have a licence under the Private Security Personnel and Private Investigators Act 2010. This law reform resulted from a Law Commission report ${ }^{39}$ that recommended licensing of repossession agents in part to address the problem of harassment of debtors by such agents. ${ }^{40}$

\section{Recommendation relating to conduct by debt collectors}

The FTA prohibition on harassment and coercion in s 23 should be amended to bring it into line with the wording in the Australian Consumer Law and breach of s 23 made an offence. The Commerce Commission should then develop detailed guidelines setting out the regulator's views on what constitutes harassment under s 23 FTA, using the Australian Debt Collection Guidelines as a model.

37 See Stace, above n 24, for a discussion of these cases.

38 Stace, above n 24

39 Law Commission Consumers and repossession a Review of the credit (Repossession) Act 1997 (NZLC R124 2012).

40 At 6.90 . 


\section{$B$ Addition of Fees and Interest to the Debt}

\section{The data}

Many mentors reported that the debt increased after being handed over to a debt collector, either by the addition of fees or by reason of interest (or default interest) continuing to accrue. In many cases the debtor did not understand how the debt had increased to the amount that was being claimed by the debt collector. For some, the fact the debt had increased led to "giving up" on trying to repay.

Below are some representative extracts from the data demonstrating a lack of understanding:

With most of my clients, the debt that they come to us with is far greater than the debt they started with, often because of all the fees and the interest. [...] Within the agreements they sign, that is often there. The client just doesn't understand that it is going to be the nature of the beast.

Because many have not understood the documents they have signed, the additional fees/charges over and above the interest rate charge, is overlooked or misunderstood. They do not appreciate/recognize how these charges make the cost of borrowing so expensive.

But the young people I'm dealing with, they don't look at the ... they just look at the interest rate and not the penalty rates or not the finer details.

Mostly clients don't understand that when a debt goes to a debt collector that there are going to be those additional charges. And they get quite irate that 'it was only this amount and now it's this amount'.

The following representative extracts relate to an inability to pay back the increased debt:

The clients keep defaulting and then the penalties on that, it just seems like a never-ending cycle. A lot of our clients, the amount that they can pay, sets them up to fail because they can never get on top of that original debt.

When the debt goes unpaid, the fees and charges and extra interest is astronomical and rises significantly more than what the client can handle.

[Client says] 'oh I've got this debt from the debt collection but it says this was my debt but there's this huge amount in costs'. And they say, 'I can't even pay the first debt how am I going to pay the costs associated with the collection'. [...] I had one last year that had $\$ 1300$ collection costs on a debt of about $\$ 5000$.

I don't think they would have been able to pay the original amount but when the fees are added there is no way, so they give up. So, it is insurmountable.

There was some suggestion that unreasonable fees had been charged:

I had one collection company and they actually charged a fee for the debt to be in transit. 
I said 'what does this even mean?' and they said 'when we buy the debt and then it sits with our team, it can sit there for a few weeks because we only have a certain amount of debt we can afford to buy on a monthly basis.' I said 'so you're telling me if it is six weeks before you can buy that debt outright, it sits in transit for all that time, and you charge fees on that.' They said 'it still has to be administrated.'

Some charge a fee just to make a payment. So, if you pay $\$ 10$ a week, you're actually only paying $\$ 9$ a week and paying a $\$ 1$ for each transaction which I think is really unfair. Someone's trying to pay something off, if you want to pay $\$ 10$ a week you have to pay $\$ 11$ to actually pay that $\$ 10$.

I am just looking into some of my clients and when I look at what they are charged extra on top of, you know all these extra fees - they pay for a letter, they pay even to close an account.

Another scenario is, I have had a client where they have made extra repayments which don't appear to have been recorded on their debt. One was told 'I am going to send the heavies around to your workplace', it was only when she then, under this duress, made a payment she couldn't afford, so used her rent money etc. to make a payment to the debt collection, the debt collectors then said to her, 'I have already arranged for the people to come round to your workplace, I still have to pay them, you now have to pay them herself', so they forced her to make an additional payment to stop the heavies, for want of a better word, from going around. That was never recorded against her debt as a payment or anything. It just seemed a little bit underhand.

Sometimes interest continued to be added to the debt:

The woman that I'm working with at the moment, she has a debt that is still collecting $26 \%$ interest on the debt itself. The debt collection company is collecting it on behalf but they haven't stopped the interest. Her $\$ 6000$ debt is close to $\$ 10,000$ because it's just continually collecting that $26 \%$.

The other thing is that some debts are actually bought with the interest component. That's a killer. The client is probably just never going to pay it off because the interest component just keeps them in the debt cycle.

Some continue to charge interest while it's being collected. [...] I mean that's just ridiculous. If it's gone to debt collection, you know, it's normally been months where people haven't paid or obviously are not in a position to pay. I don't really understand that kind of behaviour at all.

Loans and debts that are still interest bearing even after going to collections and the lack of willingness to amend this. This to me outlines a real lack of understanding of the financial hardship many people face. If someone is already struggling to pay to point that the debt is transferred to collections then continual charges are not going change this.

There was information given that suggests some debt collectors are allowing interest to accrue for several years before they collect the debt, then getting an attachment order to collect weekly payments from the debtor: 
Essentially the creditor, sometimes they've purchased the debt; sometimes they were the original creditor. But what they did is, it's this thing of adding interest after the person has clearly defaulted and is unable to pay. They added interest, in some cases, for five or six years before going to Court, and so, of course, by the time they got to Court, a $\$ 2,000$ debt had turned into a $\$ 7,000$ debt. The Court - there was never any scrutiny of these claims and so the judgment was given and then it's just a gravy train. Particularly if it's a long-term beneficiary, MSD is obliged to collect the debt because it's a court order essentially. So that $\$ 7,000$, they just sit back and the money rolls in.

\section{Comment on fees and interest}

Given that fees and interest attract different regulation, the discussion below is separated into first, discussion of issues relating to interest, and then, issues relating to the addition of fees and other charges.

(a) Interest

The obligation to pay interest (including default interest) on any amount owing primarily arises from the contract between the lender and borrower. The obligation commonly arises in the context of a loan, for example, from a finance company, but could also arise in the context of an unpaid invoice for services if the contract allows the provider to add interest to the unpaid amount, for example, on an unpaid power bill. There is no law which prevents a lender or service provider or their assignee, from continuing to charge interest or default interest on the amount owing after the debt has gone to debt collection or been assigned. There is also no law regulating the amount of interest or default interest charged, outside of a high-cost lending context.

There are some (limited) statutory restrictions on the addition of interest to a consumer credit contract debt. Part 2, sub-pt 5 of the CCCFA provides for rules around interest charges for consumer credit contracts. Under ss 36-40, for example, the contract must specify an annual interest rate and a creditor cannot require payment of an interest charge before the end of a day to which an interest charge applies. The CCCFA also provides special rules for high-cost consumer credit contracts. ${ }^{41}$ The CCCFA places a rate cap on these high-cost contracts, being 0.8 per cent of the amount of credit

41 See Credit Contracts and Consumer Finance Act, ss 45E-45K. A consumer credit contract is considered "high-cost" where the annual interest rate is 50 per cent or greater; the weighted average annual interest rate applied to the unpaid balance is likely to be 50 per cent or greater on any day of the contract; the total interest charges (including default charges) applied cumulatively is 50 per cent or greater; or where the contract is declared by regulations to be high-cost. See s 45C. 
provided per day. ${ }^{42}$ The imposition of compound interest is prohibited, ${ }^{43}$ and the total interest and fees on a high-cost consumer credit contract are capped at 100 per cent of the amount advanced. ${ }^{44}$

The CCCFA requires detailed disclosure of the terms around interest charges, including the interest rate and any default interest that may become payable, before the contract is entered into. 45 The new debt collection-specific disclosure requirements due to come into effect in late 2021 will require disclosure of the rates of any ongoing interest charges that will be made after debt collection starts, to the extent those are ascertainable. ${ }^{46}$ This new law may assist in addressing the issue of lack of understanding around the continued addition of interest to debt after the debt collection process has started.

One issue of concern that emerged from the data is that some debt purchasers appear to be deliberately letting time go by before the debt is enforced, in order to increase the debt by the addition of interest. Coupled with the use of attachment orders, this can result in a debtor having a millstone of debt for years, resulting from an initial debt that was relatively small.

The CCCFA gives the court power to reopen a credit contract (in other words, a contract under which credit is or may be provided) if it considers that a party to the contract has exercised a right under the contract in an oppressive manner. ${ }^{47}$ Under s 118 , oppressive conduct is conduct which is "oppressive, harsh, unjustly burdensome, unconscionable or in breach of reasonable standards of commercial practice." Section 124 provides a number of guidelines that the court must consider in relation to reopening of credit contracts. As explained below, there is case law that suggests that waiting for interest payable under a credit contract to accrue for several years before seeking an attachment order is likely to amount to oppressive conduct.

When claims for liquidated damages are filed in the District Court and a defendant takes no action, generally a deputy registrar will grant judgment by default. However, in about mid-2015, deputy registrars became concerned about high interest rates, periods of time allowed to elapse from a borrower's default before a claim was brought (during which period interest continued to be claimed) and the collection costs and other charges being claimed by lenders. As a result, where registry staff had concerns, the file was referred to a Judge for further direction. ${ }^{48}$ Usually this led to the

42 Section $45 \mathrm{H}$.

43 Section 45I.

44 Section 45E.

45 Section 17.

46 See reg 23 of the Credit Contracts and Consumer Finance Regulations 2004 (inserted by the Credit Contracts and Consumer Finance Amendment Regulations 2020, reg 11).

47 Credit Contracts and Consumer Finance Act, s 120.

48 Real Finance Ltd v Setefano [2016] NZHC 2293 at [12]. 
applications for judgment by default being referred for formal proof. When this happened, the Judge might decide to reopen the contract on the grounds that the creditor's conduct amounted to oppression.

In Aotea Finance $v \mathrm{Hiku}^{49}$ the lender attempted to claim a debt of $\$ 19,694.49$, which had increased over the almost five-year period since the initial \$1,443 advance. The District Court Judge adopted the view that a finance company should take legal proceedings culminating in judgment by default within one year of the borrower defaulting on their contractual repayment options. In response to the Court's threat to reopen the contract on the basis of oppressive conduct, the lender limited its claim to the interest that accrued in the period of the first year of default.

In both Real Finance Ltd $v$ Setefano $^{50}$ and Diners Club (NZ) Ltd $v$ The District Court at Auckland, ${ }^{51}$ the High Court held that the Court has jurisdiction to reopen a contract under s 120 of the CCCFA, despite the debtor not appearing. These actions came before the Court due to concerns over high interest rates, debt collection costs and the period of time allowed to elapse from a default before a claim, whereby the interest continued to be claimed.

In Diners Club, the Court had evidence from the Commerce Commission that borrowers who are the subject of default judgment proceedings are often vulnerable people with limited financial means, and are unable to effectively challenge oppressive credit contracts. ${ }^{52}$ The Court accepted that this evidence demonstrated that borrowers cannot reasonably be expected to routinely protect their own interests under the CCCFA. ${ }^{53}$

These decisions provide support for the proposition that leaving credit contract debt for a period of any more than one year after default before enforcement action is taken may result in the contract being re-opened by the court under s 120 for being oppressive conduct. As stated in Aotea Finance, this one-year period from default by the debtor "now seems to have been accepted by most, if not all, of the finance companies". ${ }^{54}$ While there was no suggestion in the data that this issue arose outside of a credit contract context, it is not impossible that it could happen in relation to non-credit contract debts, such as an unpaid power bill. While the oppression remedy is not available in this context, the prohibition on unconscionable conduct currently passing through Parliament in the Fair Trading Amendment Bill may be relevant. Being inserted as the new s 7 of the FTA, the provision states that a person must not, in trade, engage in any unconscionable conduct. Australia has a similar prohibition

49 Aotea Finance (West Auckland) Ltd v Hiku, above n 6.

50 Real Finance Ltd $v$ Setepano, above n 48.

51 Diners Club (NZ) Ltd v The District Court at Auckland [2017] NZHC 2616.

52 At [49].

53 At [52].

54 Aotea Finance (West Auckland) Ltd v Hiku, above n 6, at [12]. 
on unconscionable conduct in the Australian Consumer Laws. As earlier discussed, the New Zealand courts are likely to draw on Australian law when interpreting the phrase "unconscionable conduct".

This prohibition could potentially be used to prevent a creditor (including a debt purchaser) from engaging in delaying tactics, such as those seen in Aotea Finance, in relation to a debt that was not a credit contract. In particular, it could prevent this where it appeared there was a deliberate strategy of letting debt mount over an extended period before taking enforcement action, especially if the debtor was known to be a beneficiary.

(b) Fees

Whether the debtor is responsible to pay fees and charges incurred in the debt collection process is primarily determined by the original contract between the lender or service provider and the debtor. Commonly, the agreement will state that if the debt goes to collection, any fees or charges associated with the collection may be added to the debt, and therefore become payable by the debtor.

If the debt collector is an agent of the lender or service provider, the contract between the agent and lender or service provider will commonly state that the agent's fee is a percentage of the debt collected. This percentage is then added to the debt that is payable (being a fee or charge associated with collection). If the debt is sold, the debt purchaser takes on the rights of the lender or service provider and may charge the debtor collection fees or charges if the original contract allows. There is no formal industry standard which regulates how fees and charges associated with debt collection are calculated, nor who bears these costs. ${ }^{55}$

If the contract is a consumer credit contract, the CCCFA is relevant. The Act requires disclosure at the time the contract is entered into, including of default fees. ${ }^{56}$ Section 41 of the CCCFA provides a prohibition on unreasonable credit or default fees. "Default fees" are defined as fees or charges payable on breach of a credit contract by the debtor or payable on enforcement of a credit contract by a creditor. This is separate from default interest charges. The Commerce Commission takes the view that all fees charged by a debt collector are default fees and therefore subject to the requirement of reasonableness. ${ }^{57}$ The creditor (either the original lender or debt purchaser) is the party subject to the

55 Although a small number of New Zealand debt collectors are members of the Financial Services Federation, there is no specific industry body for debt collectors.

56 Credit Contacts and Consumer Finance Act, s 17. Default fees are defined as fees or charges payable on breach of a credit contract (s 5). Fees surrounding high-cost loans have additional rules. Per s 45J, if the contract provides for a default fee more than the prescribed amount $(\$ X)$, this fee is presumed to be unreasonable. The creditor is able to rebut this presumption if they are able to prove, on the balance of probabilities, that the fee is reasonable.

57 The Commerce Commission guidelines issued following the Supreme Court judgment in Sportzone Motorcycles Ltd (In Liq) v Commerce Commission [2016] NZSC 53 make clear that where a lender outsources debt collection or loan enforcement, (virtually) all collection and enforcement costs (there are some minor 
obligation of reasonableness and reasonableness which is to be assessed objectively. When the court is determining whether a default fee is unreasonable, under s $44 \mathrm{~A}$ the court must consider whether the fee reasonably compensates the creditor for any cost incurred, being a reasonable estimate of any loss incurred by the creditor as a result of the debtor's acts or omissions. The court must also have regard to reasonable standards of commercial practice. ${ }^{58}$

The Responsible Lending Code provides guidance on how to comply with the CCCFA, and includes a section on reasonableness of fees. The default fee should only seek to compensate the creditor for the costs and losses incurred as the result of default. Fees charged by a third parties are a cost to the creditor. The Code states that costs recovered from default fees should be consistent with reasonable standards of commercial practice. ${ }^{59}$

Under the initial disclosure requirements in the CCCFA, default fees must be described but the CCCFA does not make it clear whether disclosure must include detail of the actual amount of the fees that will likely become payable if the debt goes to collection. This seems somewhat contrary to the idea of full disclosure given that those fees can be large. For example, 20 per cent of the debt might be added on as the fee charged by the debt collection agent. ${ }^{60}$ While the exact amount of the fee may not be ascertainable, it would be helpful to require disclosure of the potential size of the default fee, as this would give the borrower more information about the consequences of default.

The data and evidence from the MBIE review suggested that many different types of fees can become payable in the course of a debt collection process, not just the debt collection agent's commission. For example, the debtor might be charged for a letter sent by the collector or for making a payment. Each of these fees has the potential to be challenged as an unreasonable fee. Following the Supreme Court's decision in Sportzone, there is no doubt that fees under consumer credit contracts cannot be used to generate profits or to recover business costs that are not closely connected to the transaction between the borrower and lender.

If a fee is provided for under a consumer credit contract that attempts to recover third party collection or enforcement costs, the fee is also able to be considered under the oppression provisions in the CCCFA. The "front loading" of lending agreements with commission costs (which are other fees and collection costs that are often charged as a percentage of the loan without any reference to

exceptions) passed on to the borrower are considered default fees, and thus are subject to the unreasonableness prohibition under ss 41 and 44A. See Commerce Commission Consumer Credit Fees Guidelines (June 2017).

58 Credit Contracts and Consumer Finance Act, s 44A (2).

59 Ministry of Business, Innovation and Employment Responsible Lending Code (as revised February 2021) at [10.5]-[10.7].

60 See Commerce Commission "Submission on the June 2018 Discussion Paper: Consumer Credit Regulation", above $\mathrm{n} 7$, at 67 . 
the actual cost incurred by the lender) was a factor that the Judge considered oppressive in Aotea Finance.

Therefore, there are legal avenues available to challenge the amount and types of fees being charged in the course of the debt collection process, in particular, if the contract is a consumer credit contract. In reality, any enforcement action would have to be taken by the Commerce Commission, so the effectiveness of these provisions requires resourcing devoted to this area of compliance. One recommendation which may assist would be to set out guidance on the Commission's approach to assessment of reasonableness of fees. This could be done in the proposed New Zealand Debt Collection Guidelines, and may assist with the development of industry standards.

There would appear to be significantly less legal protection from unreasonable fees in relation to non-consumer credit debt. Some industries have self-regulation that provides guidance on how to deal with defaulting customers. For example, the Consumer Care Guidelines issued by the Electricity Authority recommend how retailers should engage with customers on a variety of issues including when a customer is having difficulty paying a bill. Fees payable on disconnection should be reasonable and referral to the services offered by financial mentors is encouraged. ${ }^{61}$ Such measures are useful but do not specifically address the issue of unreasonable fees charged in the debt collection process.

\section{Recommendations relating to fees and interest}

The proposed New Zealand Debt Collection Guidelines should address the practice of allowing a credit contract to lie dormant for several years before commencing legal action to recover it, clarifying that this is likely to amount to oppressive conduct. The guidelines could also set out the regulator's approach to assessment of reasonableness of fees as a way of setting industry standards.

Thought should be given to the possibility of amending the CCCFA to provide a prohibition on charging interest (or default interest) in relation to a consumer credit contract once the debt collection process has started. The initial disclosure rules under the CCCFA should also require more detailed disclosure of the fees and charges that might become payable in the event that the debtor defaults and a debt collection procedure is commenced.

\section{Attachment Orders}

\section{The data}

The use of attachment orders against benefit and wages appears to be reasonably common. As discussed below, data obtained from the Ministry of Justice shows that between 2018 and 2020, around 83 per cent of attachment orders made were to benefits. Many debtors seem to be unaware of the process until after the attachment order has been made. Many mentors mentioned a standard

61 Electricity Authority Consumer Care Guidelines (1 July 2021) at [43] and [109]. 
amount of $\$ 30$ per week against a benefit. Sometimes this would mean there was insufficient money remaining for the debtor to meet regular household expenses, including food.

There appear to be two main issues arising out of the use of attachment orders. The first is that the debtor is often not aware of their rights in relation to the court process, in particular, the right to appear at the hearing where the order is made and the right to apply to have the amount reduced. The second is that the courts do not appear to be carefully considering whether the debtor can afford the amount of the deduction.

The following are representative extracts from the data:

Lack of awareness of the process or rights:

I see quite a few who go 'oh I didn't know that' or 'I didn't even know that had gone to court' and its only because we get a break down of their benefit and ask what's this for 'oh well I don't know', 'oh it's an attachment order' and we can't just stop an attachment order.

I do know that the clients have the opportunity to turn up to court and put their side forward. I know of one in particular they didn't get the paperwork until after the order was made or whether it's just the postal system but a lot of the clients are quite transient anyway so they will never get that mail saying you could be or should be appearing to put your case forward. So, they don't have a leg to stand on. That, and it's a really confronting process having to show up to court to front up to someone you owe money to and then having the justify why you can't afford to pay. There's a lot of shame and embarrassment involved in that as well as the intimidation as well.

Often the client will have decided that they will not open emails or letters because they are not able to deal with the debt and the information about the attachment order process comes in by email or letter and the client will not have seen it. [...] They do not engage with the process because they feel threatened, they are afraid as they know they have defaulted, they don't understand the process and finally they feel overwhelmed.

Affordability of the amount awarded:

No one on a benefit, it's usually $\$ 30$ a week, and nobody can afford that on a benefit.

They might say it's $\$ 30$ a week you have to pay back, it goes straight from their benefit, because it is mostly beneficiaries, they haven't actually done a budget, or they have but they haven't been given the proper preparation to do a proper budget. So, they say oh you can pay this back but when you look at the bigger picture, $\$ 30$ is actually unreasonable because otherwise they would have been paying the debt in the first place most likely.

But just being realistic, especially people on a benefit $\$ 30$ is a lot, that might be their food money for the week. 
When it comes to beneficiaries, they are most affected by these attachment orders and it's because it's set at that benchmark which seems to be $\$ 30$ a week. And it doesn't matter how much you owe, it just always seems to be set at $\$ 30$ a week.

There's another company who we deal with who are really difficult, the way they operate is, they get the debt and in order to get payment on it they take it through the court and they get an attachment order, it seems like they've worked out the core process is pretty easy to get through. In terms of they don't have to present much information. If they present with a debt saying this is how much they owe, the court just kind of rubber stamps it and they get their attachment order. It just causes all sorts of nightmares. People who come in here on benefits, after their basic essential living needs are met, they run at a deficit. So they already can't afford to pay the power, purchase food. Rent is always the top priority, then power, then water, and food always sits at the bottom of the list. And every beneficiary client of mine with debt, not one of them has any surplus in their budget. They all run at a deficit.

I think that the attachment orders, they should be outlawed to low income and it shouldn't be a practice that's allowable under law for people on low incomes and beneficiaries. Low incomes can be the same amount, if people are on basic wage it's very similar to what a person on a benefit might be getting. I do think it's very damaging, it just compounds hardship. It's sort of a no brainer. Attacking a person while they're down.

There doesn't seem to be consideration to what else is deducted already. I had a client with a 1 year old [child] once her rent and deductions were taken she was left with $6 \mathrm{c}$ of her benefit.

Sometimes it's $\$ 99$ [in the benefit] that is issued to the client after the deductions from their benefits. So then their power, their food, it's not enough. I'm telling you it's a huge problem for these beneficiaries, especially with these collection agencies as well, people have $\$ 5$ dollars here, $\$ 10$ dollars here with another collection agency ... it's a problem there. Those attachment orders can't see the financial reality for the client. It's like a reinforcement, taking that money from them when they have hardly any money left. The reality is there is no money for food, there is no money for petrol, and because of the attachment order ... it's just a redirection of the benefits to go to the collection agency.

A very recent client came through. He was a beneficiary. After all the attachments go out he was left with $\$ 10$. So how is he meant to survive? It was mind blowing, because he hasn't even paid for his power, his food, the basic things of living.

\section{Comment on attachment orders}

Sections 154-62 of the District Court Act 2016 outline the law on attachment orders made by that Court. The District Court may issue an attachment order in the circumstances referred to in ss $139(2)$ 
and 153(1) or by application. ${ }^{62}$ Commonly, the creditor will apply for an attachment order after judgment for the debt has been obtained.

A creditor (including a debt purchaser) can apply for an attachment order. ${ }^{63}$ They must have a judgment in their favour, ${ }^{64}$ complete the form provided by the Ministry of Justice, serve a copy on the other party ${ }^{65}$ and pay the application fee. ${ }^{66}$ The Court may make the attachment order even though the other party has not had the opportunity to make a representation to the Court. ${ }^{67}$

If a creditor does not have the information required to complete an application, which includes stating the debtor's employment details, they can apply for the Court to obtain and assess the debtor's financial information in a number of ways, such as phone call by the court registrar. In the case of a beneficiary, it would seem that all the creditor needs to know about the debtor's income is that they are a beneficiary and state that the Ministry of Social Development is the employer. It is then up to the Court to decide on the amount of the order. The data suggests that it is not uncommon that the Court will have no more information than the fact the debtor is a beneficiary.

The attachment order must not result in the debtor's earnings falling below the protected earnings rate. ${ }^{68}$ The protected earning rate, under s 157(6) of the District Court Act, is either 60 per cent of the net earnings for the earning period, the amount referred to in s 156(d), or an amount detailed by the judge in the attachment order. The data suggests that attachment orders against benefits are commonly for $\$ 30$ a week. The data also suggests that, where the Court has no other information than the fact the debtor is a beneficiary, it assumes that the protected earnings level is not exceeded. This may be incorrect, as the debtor may have other debt obligations of which the court is unaware.

A debtor may apply to the District Court at any time for an attachment order to be varied, suspended or discharged. ${ }^{69}$ The Court may vary, suspend or discharge the attachment order if "good cause" is shown. ${ }^{70}$

62 District Court Act 2016, s 155. Attachment orders can also be made under the High Court Rules. The attachment orders seen by mentors would commonly be made under the District Court Act.

63 District Court Act, s 155(1)(c).

64 Section 155(1).

65 Section 155(2)(a).

66 See Application for an attachment order (Ministry of Justice Collections Unit, MOJ204/10/19, 2019).

67 District Court Act, s 155(2)(b).

68 Section 157(3).

69 Section 161.

70 Section 161(3). 
Between 2018 and 2020 a total of 91,610 attachment orders were made. ${ }^{71}$ A total of 15,171 (16.6 per cent) of these were to wages. A total of 76,439 (83.4 per cent) of these were to benefits. Similar figures can be seen in the first five months of data for 2021.

Between 2018 and 2020 there was a total of 47,109 applications to suspend, vary or cancel an order. ${ }^{72}$ In this period there were 93 successful suspensions, 44,348 successful variations and 564 successful cancellations. In total, there were 45,005 successful suspensions, variations or cancellations, which amounts to 95.5 per cent of the applications to suspend, vary or cancel made in the same period. This means that the equivalent of 49.1 per cent of the attachment orders made in this period were cancelled, suspended or varied.

Even when the process to vary, suspend or cancel an order is successful, the money taken through the attachment order while the process is being completed has negative effects. For example, one financial mentor said:

[The client] couldn't afford it and she had to file papers with the court to reverse it. And that took time and in the meantime they were taking the money out of her benefit, so she ended up with $\$ 90$ taken out of her benefit when she couldn't afford it at all.

In Australia, government benefits are protected from attachment orders under s 62 of the Social Security Administration Act 1999 (Cth). The introduction of this protection appears not to have been a piece of significant law reform in light of debt collection practices, but is meant to give legal force to the intention that benefits are designed to provide income support. ${ }^{73}$ Once a benefit has been paid to the individual's bank account, it is not protected, so can be subject to an instalment or garnishee order on the account. ${ }^{74}$ However, partial protection is still afforded, as a court order will not apply to the "saved amount". ${ }^{75}$ The "saved amount" is the total amount paid into the account in the previous four weeks immediately before the order was made minus the total amount withdrawn from the account in the same period. ${ }^{76}$

In the state of Victoria, those whose sole income is from government benefits are afforded extra protection. Under s 12 of the Judgement Debt Recovery Act 1984 (Vic), they cannot be the subject of an instalment order. The primary focus of this Act was to abolish the procedures that allowed debtors

71 "Count of attachment order application by grant year (2018-2021)" (Obtained under Official Information Act 1982 Request to the Ministry of Justice).

72 "Count of applications to vary, suspend or cancel an attachment order for civil debt and their outcomes (2018-2021)" (Obtained under Official Information Act 1982 Request to the Ministry of Justice).

73 Australian Government Social Security Guide (10 May 2021) at [8.4.3].

74 At [8.4.3].

75 Social Security (Administration) Act 1999 (Cth), s 61(1)(c).

76 Section 62(2). 
to be imprisoned where they failed to pay their debts when they had the means, to create a process for instalment orders, and "to introduce more humane and effective procedure."77 In the Legislative Council debate, lawmakers noted the vulnerability of consumers, specifically, a lack of knowledge regarding interest rates and the consequences of not paying debt. ${ }^{78}$

\section{Recommendation relating to attachment orders}

A review of the use of attachment orders by creditors (including debt purchasers) should be undertaken with a view to considering whether the District Court Act 2016 should be amended to protect income from Work and Income (in other words, a benefit) and possibly an equivalent threshold for wages, from being collected under the attachment order process. At the least, the Court should be required to view more detailed information on the debtor's financial situation before it makes an attachment order that affects a debtor who is a beneficiary.

\section{CONCLUSION}

The 2021 Research has revealed that there are serious issues with how debt is being collected in New Zealand. The data suggested that harassment of debtors is common, that there is a general lack of understanding around the addition of fees to the debt, and in some cases there is the addition of unreasonable fees. Some debt collectors appear to be allowing interest to accrue for several years before seeking a default judgment, then obtaining an attachment order to pay off a debt significantly in excess of the original amount borrowed. Many debtors have little understanding of their rights to challenge the amount of an attachment order and it is common for an attachment order to be made against a benefit, often in circumstances where the court does not have full information on the beneficiary's financial commitments.

The law can assist. The FTA prohibits conduct that amounts to harassment in trade, including in the course of the debt collection process. That law can be harnessed to address much of the conduct that that was described by the financial mentors interviewed. An effective way to do that would be to introduce detailed guidelines as exist in Australia, which, for example, specify the times of day that it is appropriate to contact a debtor, limit contact at the workplace and limit the number of times a debtor can be contacted. However, the differences in the wording of the FTA prohibition and the equivalent prohibition in Australia, as well as the penalties for breach, need to be addressed before those guidelines can be developed. Such guidelines could also set out the regulator's view of when debt collection conduct will amount to oppression and what are likely to be unreasonable fees under the CCCFA.

What is clear is that problems debtors face must be addressed with compassion. While there may be cases where a person has deliberately set out to borrow (or otherwise incur debt) and not repay, no

77 (18 April 1984) 374 VPD (Legislative Council) at 2352.

78 At 2353 
evidence of this emerged from comments made in the research. The following quote is representative of the situation faced by financial mentors who regularly see clients that have got into an unmanageable debt situation:

We get clients in here all the time, and at the time the debt was incurred, they could actually afford it. And then something changes in their lives where they are no longer able to afford it. They actually just don't have the know-how or the skills to be able to re-negotiate it and find out what can be done and it just gets all too overwhelming for them, so they just leave it and then it eventually ends up with debt collection and then it just disadvantages them forever. It affects their credit rating, lots of things. It makes them feel like crap, that they're worthless, that they've failed themselves. 
(2021) 52 VUWLR 